\title{
Kroniske muskelsmerter kan forklares på mange måter
}

\author{
Sammendrag \\ Bakgrunn. Pasienter med kroniske \\ muskelsmerter har uttalte plager til \\ tross for normale funn. At plagene \\ oppfattes som uforklarte, betyr \\ imidlertid ikke at de er uforklarlige. \\ Nyere forskning gir god innsikt i hvor- \\ dan kroppslige og mentale prosesser \\ og livsbetingelser er tett sammenvevet \\ med hverandre. Dette gir mulighet for \\ forståelse og endring av forhold som \\ påvirker sårbarhet og motstandskraft.
}

\begin{abstract}
Materiale og metode. I artikkelen presenteres en sammenfatning av teoretiske perspektiver, empiriske funn og kliniske erfaringer og drøfting av hvordan dette kunnskapsgrunnlaget kan omsettes til klinisk praksis.
\end{abstract}

Resultater. Belastninger kan føre til dysregulering via spinal sensitivering og vedvarende stressaktivering. Psykonevroimmunologi beskriver hvordan subjektive erfaringer, emosjoner, kognitive funksjoner, nervesystem og stressfysiologiske responser samvirker for å gjenopprette balanse via komplekse signalsystemer. Forløpet påvirkes av emosjonelle og kognitive prosesser, avhengig av individuell sårbarhet og styrke.

Fenomenologiske perspektiver fokuserer på livsbetingelser, mening og tolkning av kroppslige signaler. Ved å anerkjenne pasientens erfaringer kan vi skape nye dialoger, forebygge kampen om definisjonsmakten og flytte fokus fra skam til mestring.

Fortolkning. Kroniske muskelsmerter kan forstås i lys av samspillet mellom kropp, sjel og livsbetingelser. Det er lite å vinne på å lete etter enkle årsaksforklaringer og entydige funn. I stedet bør vi stimulere til mestring og bidra til å bryte onde sirkler som vedlikeholder symptomene.

\section{Kirsti Malterud}

kirsti.malterud@isf.uib.no

Allmennmedisinsk forskningsenhet Bergen Unifob Helse

Kalfarveien 31

5018 Bergen

og

Institutt for samfunnsmedisinske fag

Universitetet i Bergen

Som allmennlege møter jeg mange pasienter med langvarige muskel- og skjelettsmerter. Slike helseplager utgjør et betydelig folkehelseproblem og kan føre til funksjonssvikt med langtidssykmelding eller uførhet. Lidelsestrykket kan være stort, og når smertene fører til at hverdagen endres, blir pasientens identitet og mestring utfordret. Hos noen kan plagene skyldes degenerative lidelser som artrose eller inflammatoriske lidelser som leddgikt, men flertallet lider av tilstander som klassifiseres som belastningslidelser (1), også kalt bløtdelsrevmatologi, myofasciale smerter, lumbago, tendinitter, tendinoser eller myalgier. Symptomene oppstår når muskler, sener og ledd reagerer på en eller annen form for langvarig eller ensidig belastning (1). Smertene kan være lokalisert (oftest nakke, skulder, rygg, armer) eller generalisert, som ved fibromyalgi. I medisinsk dagligtale snakker vi om kroniske muskelsmerter, selv om flere strukturer enn muskulaturen er involvert (2). Kroniske muskelsmerter kjennetegnes av uttalte symptomer til tross for normale funn ved klinisk undersøkelse, bildediagnostikk og blodprøver. Disse blir gjerne kalt «medisinsk uforklarte symptomer» (3-4)

Men «uforklart» er ikke det samme som «uforklarlig». Nyere teori og empiri gjør at vi kan forstå mer om sykdomsmekanismene og dermed gi bedre helsehjelp til en stor pasientgruppe. Fra min egen forskning har jeg erfart at flerfaglige tilnærminger kan være nyttig for å forstå komplekse fenomener når menneskelivet i menneskekroppen utsettes for belastninger og utfordringer. I denne artikkelen vil jeg presentere noen perspektiver som kan bidra til å forklare årsaksforhold og sykdomsdynamikk ved kroniske muskelsmerter og drøfte hvordan dette kan omsettes til klinisk praksis.

\section{Materiale og metode}

Jeg vil belyse problemstillingen ved å sammenfatte forskningsbaserte modeller fra ulike fagområder, supplert med kliniske erfa- ringer og vitenskapelige funn. Presentasjonen bygger ikke på systematisk litteratursøk, men på utvalg av referanser basert på min egen erfaring som allmennlege, forsker og formidler. Praksisrelevans har stått sentralt som kriterium for utvalg, prioriteringer og tolkninger.

Perspektiver fra smertefysiologi, fenomenologi og salutogenese kan bidra til refleksjon over årsaksforståelse og behandlingsstrategier ved kroniske muskelsmerter og åpne for nye forklaringer i samhandling med pasienten. Psykonevroimmunologi er en referanseramme som integrerer kunnskapsgrunnlaget fra flere ulike teoretiske posisjoner. Jeg vil prøve å vise hvordan dette rammeverket kan ta høyde for kompleksitet og bidra til innsikt i det dynamiske samspillet mellom kroppslige og mentale prosesser og livsbetingelser, slik at legen ikke lenger behøver å oppfatte kroniske muskelsmerter som uforklarte symptomer.

\section{Hva er smerte?}

International Association for the Study of Pain definerer smerte som en ubehagelig sensorisk og emosjonell opplevelse som opptrer i sammenheng med vevsskade eller truende vevsskade eller beskrives som om den skyldtes vevsskade (5). Vevsskade gjøres på denne måten til en konkret, strukturell referanse for å visualisere smertens typiske opphav eller årsaksmekanisme. Også denne definisjonen anerkjenner smerte som en grunnleggende subjektivt erfart opplevelse, uavhengig av om strukturelle endringer kan påvises.

Akutt smerte kan være nyttig for kroppen, for eksempel ved at pasienten ikke belaster et

\section{Hovedbudskap}

- Muskelsmerter skapes og vedlikeholdes av komplekse årsaksforhold

- Flerfaglige forskningsbaserte perspektiver forklarer årsaksmekanismer og sykdomsdynamikk

- Det er lite å vinne på å lete etter enkle årsaksforklaringer og entydige funn

- Vi bør stimulere til mestring og bryte onde sirkler som vedlikeholder symptomene

- Ved å anerkjenne pasientens erfaringer og kunnskap kan leger bidra til å flytte fokus fra skam til mestring 
brukket bein. Over tid kan spinal sensitivering modulere smerteimpulsene i nervesystemet slik at betydningen endres (2). På denne måten omformes akutt og hensiktsmessig smerte til kronisk smerte som ikke lenger har nyttefunksjon. Slike nevrofysiologiske prosesser samvirker med endokrine og autonome systemer. Vedvarende aktivering av stresshormonelle systemer kan forklare hvorfor smertesyndromene ofte ledsages av andre kroppslige symptomer i tillegg til muskelsmertene (6). Også de fysiologiske stressresponsene har opprinnelig en hensiktsmessig funksjon, men når den akutte situasjonen er overstått og beredskapen vedvarer, utvikles helseskadelige belastningsmønstre som til dels vedlikeholder seg selv (7).

\section{Sammensatte årsaksforhold}

De kroniske muskelsmertene utfordrer biomedisinens klassiske monokausale, lineære årsaksforståelse. Iblant finner vi en spesifikk utløsende årsak til smertene, for eksempel en innspurt med tastaturarbeid før innlevering av en oppgave med tidsfrist. Deretter kan ulike faktorer bidra til å vedlikeholde plagene, for eksempel en slitsom jobb med høyt stressnivå i omsorgssektoren. Etter hvert blir det vanskeligere å identifisere enkeltstående belastninger som kan avbrytes med konkret avlastning. Hos mange pasienter med kroniske muskelsmerter finner vi ikke noen entydig og opplagt tilgrunnliggende årsaksforklaring. Sykdom og helse utformes spesifikt hos hvert enkelt individ innenfor deres sosiokulturelle sammenheng. Individuell sårbarhet kan ha ulik bakgrunn vi vet ikke hvorfor noen utvikler kroniske muskelsmerter i en gitt belastningssituasjon, mens andre som står i tilsynelatende identiske belastninger, forblir symptomfrie.

Fenomenologiske perspektiver kan bidra til at vi fokuserer på menneskelivet, erfaringer og meningsdanning, slik at kroppen fremstår $i$ et annet lys enn $i$ et anatomisk atlas. Livsbetingelser og tolking av kroppslige erfaringer har stor betydning for hvordan kronisk smerte oppstår, utvikles og oppleves. Dette blir tydelig i møte med pasienter med kroniske muskelsmerter, der årsaksforholdene ofte er sammensatte og uoversiktlige. Forhold utenfor legekontorets rekkevidde, som traumatiske barndomserfaringer, konfliktfylte familierelasjoner, kjønnsrolleforventninger eller et krevende arbeidsliv, kan ha betydning for sykdomsutvikling og symptomhåndtering $(4,8-10)$. Hos noen kan krenkende livshendelser skape varige spor som kroppen omformer til smerte (8), hos andre bidrar genetiske forutsetninger til individuell utsatthet (11). Men hos mange finner vi ingen opplagt årsak i livshistorien.

\section{Håp og mestring}

Når pasientens erfaringer får legitimitet i det medisinske refleksjonsrommet, kan hans eller hennes kunnskap om kropp og liv gi viktige bidrag til ny forståelse (12). I epidemiologis-

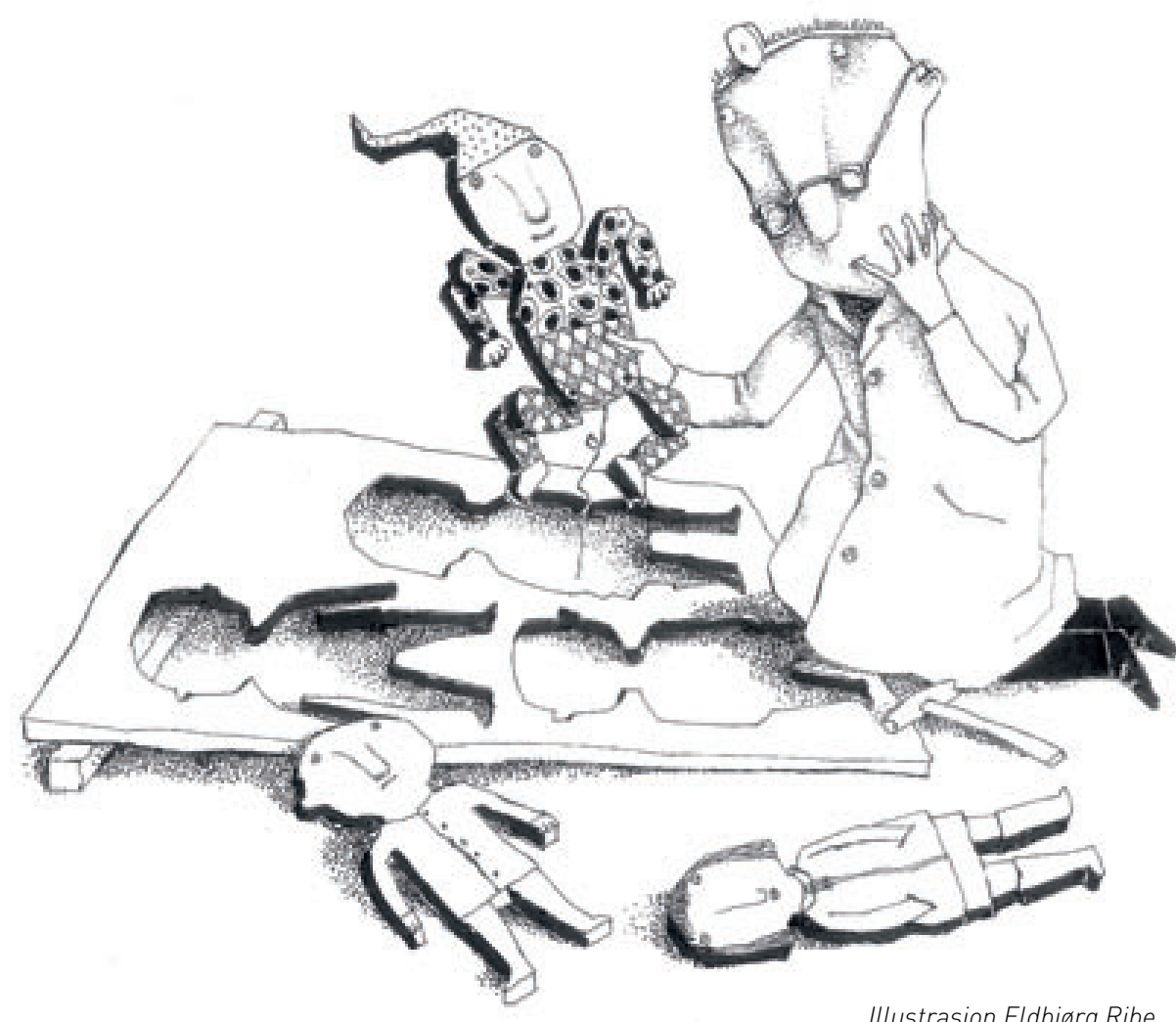

ke studier er det dokumentert at selvvurdert helse predikerer fremtidig funksjonsnivå, morbiditet og mortalitet (13). Kvalitative studier viser at pasienter har kunnskap om selvvurderte helseressurser, strategier og egenskaper som kan bidra til å motvirke sykdom og fremme helse (14). Samtidig kan negative tanker og følelser knyttet til tolkning av symptomene være med på å skape uheldige sirkler som vedlikeholder symptomopplevelser. Kognitive prosesser knyttet til tolkningen av kroppslige fenomener, spesielt stimulusog responsforventning, påvirker menneskers forhold til mestring av smerte og påvirkning av smertesirklene, uansett hvordan det hele startet (7). Det er kanskje vel så viktig å spørre etter hva som holder folk friske (salutogenese) som å lete etter hva som gjør folk syke (patogenese) (15). Ved kronisk sykdom der en opplevelse av håpløshet kan komme til å prege både legen og pasienten, vil det ha stor betydning om den felles forståelsen av tilstanden orienteres mot det som gir muligheter, håp $\mathrm{og}$ mestring, $\mathrm{i}$ stedet for det som er dysfunksjonelt og problematisk.

\section{Kropp, sjel og livsbetingelser}

Det tradisjonelle biomedisinske sykdomsbegrepet forutsetter at symptomer på kroppslig sykdom bekreftes av kliniske eller laboratoriemessige funn, mens symptomer uten funn må antas å representere psykisk sykdom eller fravær av egentlig sykdom. Ved kroniske muskelsmerter og andre symptomer som oppfattes som medisinsk uforklarte, er fellesnevneren manglende samsvar mellom det legen oppfatter som «subjektive symptomer» (det pasienten forteller) og «objektive funn» (det legen ser, eventuelt med teknologisk støtte).

Den biopsykososiale modellen ble introdusert ut fra erkjennelsen av at sykdom oppstår i et skjæringsfelt der psykologiske, biologiske og sosiale forhold påvirker hverandre og til sammen skaper sykdom eller helse. Modellen bygger på Batesons systemteoretiske forståelsesmåter og inviterer til sirkulær tenkning i stedet for lineære årsaksrekker. Engel ønsket med sin modell å gi et alternativ til en dualistisk referanseramme som krever at symptomer klassifiseres som enten somatiske eller psykiske (16).

Den biopsykososiale modellen ble supplert og konkretisert med psykonevroimmunologisk teori og empiri (17). Fagfeltet tar utgangspunkt i eksperimentell forskning om sammenhenger mellom subjektive erfaringer som stress, emosjoner, kognitive funksjoner, læring, nervesystem og stressfysiologiske responser, hvordan slike sammenhenger medieres og hvilken betydning dette kan ha for helse og sykdom $(7,18)$. Utgangspunktet er at mange ulike systemer kontinuerlig responderer på indre eller ytre påvirkninger for å opprettholde balanse. Psykonevroimmunologiske modeller har vært rettet spesielt mot interaksjoner mellom hjernen og immunsystemet, som innervering av lymfeknuter, beinmarg og cellulære systemer i tarm og slimhinner, dessuten mot signalsystemer som nevrotransmittere, stresshormoner og cytokiner (18). Læring kan påvirke immunresponser, og dette er igjen avhengig av individuell sårbarhet, for eksempel via det autonome nervesystemet eller genetiske forhold. 
Stressfysiologi står sentralt i forståelsen av psykonevroimmunologiske sammenhenger. Kroppslig aktivering, som i utgangspunktet er en hensiktsmessig alarmreaksjon på belastning, kan under gitte omstendigheter utvikles til vedvarende aktivering som sensitiverer de fysiologiske systemene og svekker individets evne til å restituere seg (6-7). Mens systemet opprinnelig var innstilt på å opprettholde en fysiologisk balanse, konsolideres i stedet en kronisk belastningssituasjon med dysregulering. Det fysiologiske begrepet «vedvarende aktivering» stemmer for øvrig godt overens med «kroppslig beredskap», et fenomen beskrevet hos kvinner med kroniske muskelsmerter som stadig står klare til å oppfatte og imøtekomme andres behov (9).

\section{Diskusjon}

Det er altså godt dokumentert at kroppslige og mentale prosesser og individuelle livsbetingelser er tett sammenvevd. Dette gir mulighet for forståelse og endring av forhold som kan påvirke individuell sårbarhet og motstandskraft. Hvordan kan slike forståelsesmåter omsettes til klinisk praksis?

\section{«Uforklart» er ikke «uforklarlig»}

Medisinsk uforklarte symptomer er ikke nødvendigvis uforklarte på ubestemt tid. Medisinsk kunnskap har begrenset holdbarhet og utvikles etter hvert som vi forstår mer. I mange år ble for eksempel magesår oppfattet som en kirurgisk lidelse som skulle opereres. Gradvis ble forklaringsgrunnlaget for sykdommen endret, og i 2005 ble Barry J. Marshall og J. Robin Warren tildelt nobelprisen for oppdagelsen av magesår som en infeksjonssykdom forårsaket av Helicobacter pylori.

Kroniske muskelsmerter er den største gruppen av medisinsk uforklarte helseplager med uttalte subjektive symptomer uten konsistente objektive funn. Betydelig komorbiditet mellom fibromyalgi, kronisk tretthetssyndrom og irritabel tykktarm har ledet til hypoteser om sensitivering som følge av vedvarende aktivering som felles underliggende mekanisme $(6,19-20)$. Etter denne modellen kan ulike forhold ligge til grunn for aktiveringen (eksempelvis virusinfeksjoner, langvarig ergonomisk belastning, alvorlige livstraumer), og ytringsformene og symptombildet kan utformes individuelt forskjellig. Til tross for fellestrekkene fremstår fibromyalgi, kronisk tretthetssyndrom og irritabel tykktarm som tilstander med ulik kliniske profil, og det er utviklet spesifikke diagnostiske kriterier for hver av disse gruppene (21-23). En tilstand kan altså få merkelappen «medisinsk uforklart» også når det foreligger diagnostiske kriterier og godt underbygde teorier om sykdomsmekanismene. Forholdene ligger godt til rette for videre forskning og ny forståelse av disse tilstandene.

For nakkeslengskade, bekkenløsning, candidasyndrom, amalgamskade, el-allergi og multippel kjemisk intoleranse er det empiriske grunnlaget dårligere dokumentert.
Likevel kan tankegangen om symptomutvikling gjennom sensitivering som følge av vedvarende aktivering også her fungere som et logisk forståelsesgrunnlag som kan hjelpe oss til å påvirke forhold som vedlikeholder symptomene (7). Kanskje har vi mer å vinne på å lete etter muligheter for å bryte onde sirkler og stimulere til mestring, enn på å lete etter enkle årsaksforklaringer og entydige funn. Samtidig er grundig klinisk utredning avgjørende for med rimelighet å kunne utelukke andre tilgrunnliggende forhold som det kan eller bør gjøres noe med. Når situasjonen er tilstrekkelig klarlagt i dialog med pasienten, fremstår kanskje ikke smertene som så uforklarte lenger.

Begrepet «medisinsk uforklarte symptomer» indikerer at det tradisjonelle medisinske sykdomsbegrepet ikke utgjør et tilfredsstillende forklaringsgrunnlag ved kroniske muskelsmerter og andre helseplager uten objektive funn. Men legens briller - det medisinske blikket - fanger ikke nødvendigvis opp alt som kan kalles objektive eller reproduserbare funn eller kunnskap som er relevant for årsaksforståelsen. For eksempel gjør fysioterapeuter karakteristiske funn hos pasienter med kroniske muskelsmerter (holdt pust med økt muskelspenning i mage, bryst og strupe, holdningsforandringer, liten avspenningsevne, dårlig balanse og problemer med å bevege kroppsdelene fritt i forhold til hverandre) (24). Ortopedisk kompetanse kan muliggjøre presis og spesifikk diagnostikk, slik at et symptombilde for eksempel kan lokaliseres til musculus infraspinatus istedenfor å kalles myalgi (1). Når muskelsmertene har en direkte sammenheng med belastninger og traumer i pasientens liv, kan det være vanskelig for pasienten selv å ta dette opp $i$ møte med legen, særlig angående overgrepserfaringer (8). I en svensk studie fortalte kvinner med kroniske muskelsmerter hvordan de håpet at legen ville skape en åpning $i$ samtalen der det var tilstrekkelig trygt for dem å fortelle om det som var vanskelig (25).

Skarpheten og dybden i det medisinske blikket kan altså styrkes, gjerne med lærdom fra andre fagfolk. Kroniske muskelsmerter er et eksempel på helseplager som tvinger oss til å lete etter bredere grunnlag for medisinsk erkjennelse og klinisk kunnskap enn det som den tradisjonelle sykdomsmodellen innebærer (26).

\section{Kampen om definisjonsmakten}

I møte med pasienter med kroniske muskelsmerter kan legen oppleve hjelpeløshet når virkeligheten stemmer dårlig overens med de medisinske lærebøkene. Skillet mellom somatisk/psykisk og objektivt/subjektivt settes på spissen når det er lite å finne ved undersøkelser og tester. Konflikter og spenninger i lege-pasient-forholdet utvikles når legen og pasienten har ulike oppfatninger om sykdomsårsak og diagnose. Da kan konsultasjonen bli en arena der partene kjemper om definisjonsmakten. Relasjonen blir ikke mindre spenningsfylt når legen klassifiserer pasienten som en vanskelig pasient eller viser negative holdninger som får pasienten til å føle skyld og skam (27). Slike motsetninger kan brytes med tenkemåter og talemåter som tar utgangspunkt i hvordan kroppslige og mentale prosesser og livsbetingelser henger sammen. Dette gir ofte god resonans hos pasienten.

Denne pasientgruppen har behov for grundig utredning og god oppfølging. For legen kan det være vanskelig å forstå hvorfor pasienten har det så dårlig, eller hvorfor anbefalingene om behandling eller opptrening ikke etterleves. Kvinner med slike helseplager forteller imidlertid om hvordan velmente anbefalinger om behandlingsstrategier og rehabilitering oppleves som urealistiske innenfor rammene av det hverdagslivet de lever (10). Det finnes altså forklaringer på dette også.

Legens ansvar er å bidra til dialog som kan skape anerkjennelse og håp og å forebygge utilsiktede krenkelser som skaper nye belastninger for pasienten (28). I min egen forskning har jeg sett mange eksempler på hvordan pasienten kan bidra til å gi legen forklaringsgrunnlag for tilsynelatende uforklarte helseplager gitt at pasienten anerkjennes som relevant kunnskapskilde (4, 12, 29). Dette innebærer ikke at legen må godta en hvilken som helst årsaksforklaring eller symptomfortolkning. Likevel gir åpne refleksjoner om sykdomsforståelse som regel nyttig informasjon som kan lede til gjensidig forståelse. Forklaringsmodeller som begge parter opplever som dekkende og meningsfulle, kan åpne for ny og bedre dialog (30). For pasienten betyr det mye at legen forstår hva plagene deres skyldes. Pasienter med kroniske muskelsmerter verdsetter forklaringer om komplekse sammenhenger for kroppslige fenomener (24). Psykonevroimmunologiske modeller kan også gi nyttig korrektiv til legfolks oppfatninger om uhensiktsmessige passive mestringsstrategier som vedlikeholder kroniske smertetilstander når folk tror det beste er å ta det med ro (31). I stedet kan legen vise hvorfor det er bedre for kroppen å være i passelig aktivitet og tilby alternative tolkninger av hva smerten kan bety.

\section{Navn gir mening - diagnosens betydning}

En diagnose kan representere en symbolsk melding om at lidelsen har sin forklaring, og aller helst at det finnes behandling og håp. Ved å få en diagnose kan pasienten legge fra seg frykt og bekymring for andre sykdommer (32). Diagnosen kan også styrke den sosiale legitimiteten av pasientens symptomopplevelse og funksjonsutfall. Hos pasienter med kroniske muskelsmerter kan det imidlertid være vanskelig å konkludere med noe annet enn en symptomdiagnose, selv når legen forsøker å tenke helhetlig. «Kronisk» kan også gi sterke assosiasjoner til noe som er håpløst.

For at en diagnose skal kunne være et bærekraftig virkemiddel for felles forståelse og endring av symptombelastningen, må legen og pasienten sammen bruke den til å skape 
betydning og innhold som kan peke fremover og bidra til positiv responsforventning - en forestilling om at det vi selv tenker om situasjonen kan gjøre en forskjell for hvordan det vil gå (7). Derfor er det ikke likegyldig hva vi kaller pasientens plager, verken på legekontoret eller i faglitteraturen. Begrepsbruken i denne delen av det diagnostiske feltet er langt fra årsaksnøytral eller verdinøytral. Hittil i denne artikkelen har jeg valgt å bruke diagnostiske betegnelser uten sterke signaler om årsaksmekanismer, som «kroniske muskelsmerter» og «medisinsk uforklarte symptomer». Et annet deskriptivt begrep som også omfatter kroniske muskelsmerter er «subjektive helseplager».

Andre vanlige begrep er «funksjonelle lidelser» og «somatiseringslidelse». Flere har påpekt at dagens omgang med disse to begrepene ofte formidler en oppfatning om at de fysiske symptomer skyldes tilgrunnliggende psykisk sykdom (33-34). Stone og medarbeidere gjennomgikk 14 amerikanske og britiske aviser fra perioden 1996-2002 for å undersøke betydningen av ordet «psykosomatisk» (35). I en av tre artikler der dette ordet forekom, ble det brukt i nedsettende betydning, eksempelvis om noe som var innbilt. I langt de fleste tilfellene ble «psykosomatisk» brukt som betegnelse på et problem med psykologisk utgangspunkt, bare unntaksvis det motsatte. Forfatterne konkluderer med at mediene trenger opplæring om den faglige betydningen av dette begrepet for at det skal kunne oppfattes som positivt av pasientene. «Diffusitas» er dessverre fortsatt en betegnelse som brukes av norske leger. Denne termen egner seg neppe for felles forståelse og allianse og bør fjernes fra medisinsk dagligtale.

Pasienter med kroniske muskelsmerter klager over at legen psykologiserer og moraliserer over deres problemer (27). Bare et mindretall av allmennlegens pasienter med medisinsk uforklarte symptomer tilfredsstiller de diagnostiske kriteriene for somatiseringslidelse etter DSM-IV (36). Når konsultasjonen blir en arena der pasienten kjemper for en somatisk diagnose, mens legen tviholder på en psykologisk forklaring, er det vanskelig å utvikle et godt samarbeid. I klinisk praksis kan det være en god investering for legen i samarbeid med pasienten å bidra til at plagene får et navn som representerer forklaring, håp og verdighet og som gir et tilstrekkelig grunnlag for felles forståelse (37).

\section{Hva så?}

Forklaring og forståelse henger ofte sammen. Det kan være vanskelig å forstå noe vi ikke kan forklare. Kroniske muskelsmerter kan ha mange forklaringer som kan begrunne strategier der prosesser som vedlikeholder symptomene brytes. Legen kan bruke dette som utgangspunkt for kognitive mestringsmodeller der pasienten lærer at smerteopplevelse utløst av aktivitet ikke nødvendigvis behøver å bety fare (7). Vedvarende aktivering kan påvirkes gjennom nye kroppslige erfaringer som endrer pasientens tolkninger av hva som er skadelig og hva som er nyttig. Treningsbehandling (38) og flerfaglig rehabilitering (39) har gitt gode resultater ved kroniske muskelsmerter. Men trening og undervisning er ikke alltid nok til å bryte onde sirkler. Mye tyder på at styrking og anerkjennelse i behandlingssituasjonen kan være avgjørende forutsetninger for endring for kvinner med kroniske muskelsmerter $(4,24,29)$. A vise pasienten forståelse $i$ praksis er noe annet enn å lete etter årsaker eller funn som en betingelse for å anerkjenne pasientens symptomopplevelse.

\section{Oppgitte interessekonflikter: Ingen}

\section{Litteratur}

1. Fossum S, Kristensen P, Hunskår S. Muskel- og skjelettsystemet. I: Hunskår S, red. Allmennmedisin. 2. utg. Oslo: Gyldendal Akademisk, 2003: $302-76$.

2. Tjølsen A, Vøllestad NK. Muscle and pain physiology. I: Malterud K, Hunskår S, red. Chronic myofascial pain: a patient-centered approach. Abingdon: Radcliffe Medical Press, 2002: 21-33.

3. Burton C. Beyond somatisation: a review of the understanding and treatment of medically unexplained physical symptoms (MUPS). Br J Gen Pract 2003; 53: $231-9$

4. Malterud K. Symptoms as a source of medical knowledge: understanding medically unexplained disorders in women. Fam Med 2000: 32: 603-11.

5. Merskey H, Bogduk N. Task Force on Taxonomy. Classification of chronic pain: descriptions of chro nic pain syndromes and definitions of pain terms. 2. utg. Seattle, WA: IASP Press, 1994.

6. Ursin H, Eriksen HR. Sensitization, subjective health complaints, and sustained arousal. Ann N Y Acad Sci 2001; 933: 119-29

7. Ursin H, Eriksen HR. Cognitive activation theory of stress (CATS). Neurosci Biobehav Rev 2010; 34: 877-81.

8. Kirkengen AL. Inscribed bodies: health impact of childhood sexual abuse. Dordrecht: Kluwer, 2001

9. Lilleaas U-B. Når forskjellen blir synlig: kvinner med kroniske muskelsmerter i et kjønnsrolleperspektiv. Oslo: Senter for kvinneforskning, Universitetet i Oslo, 1995.

10. Johansson EE, Hamberg K, Lindgren G et al. «How could I even think of a job?» - Ambiguities in working life in a group of female patients with undefined musculoskeletal pain. Scand J Prim Health Care 1997; 15: 169-74

11. Buskila D, Sarzi-Puttini P, Ablin JN. The genetics of fibromyalgia syndrome. Pharmacogenomics 2007; 8: 67-74

12. Malterud K, Taksdal A. Et felles refleksjonsrom med pasientens symptomer som gyldige kunnskapskilder. Tidsskr Nor Lægeforen 2001; 121: 3605-9.

13. Idler EL, Benyamini Y. Self-rated health and mortality: a review of twenty-seven community studies J Health Soc Behav 1997; 38: 21-37.

14. Malterud K, Hollnagel H. Women's self-assessed personal health resources. Scand J Prim Health Care 1997; 15: 163-8

15. Antonovsky A. Health, stress and coping. New per spective on mental and physical well-being. Washington D.C.: Jossey-Bass Publishers, 1979.

16. Engel GL. The need for a new medical model: a challenge for biomedicine. Science 1977; 196 129-36.

17. Ader R, Cohen N, Felten D. Psychoneuroimmunology: interactions between the nervous system and the immune system. Lancet 1995; 345: 99-103.

18. Zachariae R. Psychoneuroimmunology: a biopsycho-social approach to health and disease. Scand J Psychol 2009: 50: 645-51.

19. Bruusgaard D, Natvig B. Uklare tilstander - felles mekanismer? Tidsskr Nor Lægeforen 2009; 129 $1481-3$

20. Wyller VB, Eriksen HR, Malterud K. Can sustained arousal explain the Chronic Fatigue Syndrome? Behav Brain Funct 2009; 5: 10.
21. Wolfe F, Smythe HA, Yunus MB et al. The American College of Rheumatology 1990 Criteria for the Classification of Fibromyalgia. Arthritis Rheum 1990; 33: $160-72$

22. Fukuda K, Straus SE, Hickie I et al. The chronic fatigue syndrome: a comprehensive approach to its definition and study. Ann Intern Med 1994; 121: 953-9.

23. Thompson WG, Longstreth GF, Drossman DA et al. Functional bowel disorders and functional abdominal pain. Gut 1999; 45 (suppl 2): 1143-7.

24. Steihaug S. Fra trening og undervisning til bevegelse og samhandling. Anerkjennelse av kvinner med kroniske muskelsmerter. Doktorgradsavhandling. Oslo: Universitetet i Oslo, 2002.

25. Hamberg K, Johansson EE, Lindgren G. «I was always on guard» - an exploration of woman abuse in a group of women with musculoskeletal pain. Fam Pract 1999: 16: $238-44$

26. Malterud K. The art and science of clinical knowledge: evidence beyond measures and numbers. Lancet 2001; 358: 397-400.

27. Werner A, Isaksen LW, Malterud K. «l am not the kind of woman who complains of everything»: illness stories on self and shame in women with chronic pain. Soc Sci Med 2004; 59: 1035-45.

28. Malterud K, Hollnagel H. Avoiding humiliations in the clinical encounter. Scand J Prim Health Care 2007; 25: 69-74.

29. Malterud K. Allmennpraktikerens møte med kvinnelige pasienter. Oslo: Tano, 1990.

30. Stensland P. Malterud K. New gateways to dialogue in general practice. Development of an illness diary to expand communication. Scand J Prim Health Care 1997; 15: 175-9.

31. Werner EL, Ihlebaek C, Skouen JS et al. Beliefs about low back pain in the Norwegian general population: are they related to pain experiences and health professionals? Spine (Phila Pa 1976) 2005; 30: $1770-6$.

32. Undeland M, Malterud K. The fibromyalgia diagnosis: hardly helpful for the patients? A qualitative focus group study. Scand J Prim Health Care 2007; 25: $250-5$

33. Malterud K. «Mener han at somatisering er noe jeg gjør?» En pragmatisk begrepsanalyse. Tidsskrift for Forskning i Sygdom og Samfund 2006; nr. 5: 5-19.

34. Mayou R, Kirmayer LJ, Simon G et al. Somatoform disorders: time for a new approach in DSM-V. Am J Psychiatry 2005; 162: 847-55.

35. Stone J, Colyer M, Feltbower S et al. «Psychosomatic»: a systematic review of its meaning in newspaper articles. Psychosomatics 2004; 45: 287-90.

36. Smith RC, Gardiner JC, Lyles JS et al. Exploration of DSM-IV criteria in primary care patients with medically unexplained symptoms. Psychosom Med 2005; 67: 123-9.

37. Epstein RM, Quill TE, McWhinney IR. Somatization reconsidered: incorporating the patient's experience of illness. Arch Intern Med 1999; 159: 215-22.

38. Busch AJ, Schachter CL, Overend TJ et al. Exercise for fibromyalgia: a systematic review. J Rheu matol 2008; 35: 1130-44.

39. Wigers SH, Finset A. Rehabilitering ved kroniske myofascielle smertetilstander. Tidsskr Nor Lægeforen 2007; 127: 604-8

Mottatt 29.6. 2009, første revisjon innsendt 7.5. 2010, godkjent 27.7. 2010. Medisinsk redaktør Anne Kveim Lie. 